\title{
COHESIVE DEVICES IN ENGLISH DEPARTMENT STUDENTS' RESEARCH ARTICLES
}

\author{
AN ARTICLE \\ Submitted in Partial Fulfillment of the Requirements \\ for the Degree of Sarjana Sastra
}

By

TRIANA

Registration Number: 2132220017

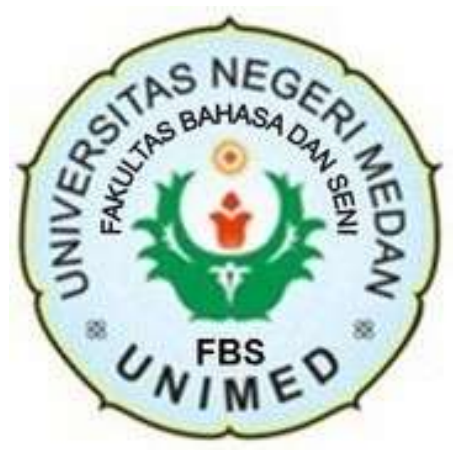

\section{ENGLISH AND LITERATURE DEPARTMENT \\ FACULTY OF LANGUAGES AND ARTS STATE UNIVERSITY OF MEDAN 2018}




\section{ARTIKEL \\ COHESIVE DEVICES IN ENGLISH DEPARTMENT STUDENTS' RESEARCH ARTICLE}

Disusun dan Diajukan oleh:

Triana

NIM. 2132220017

Telah diverifikasi dan dinyatakan memenuhi syarat

untuk diunggah pada jurnal online

Medan, September 2018

Menyetujui

Dosen Pembimbing Skripsi 1

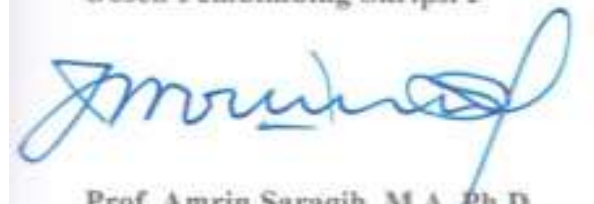

Prof. Amrin Saragih, M1.A.,Ph.D.

NIP. 195501131982031062
Dosen Pembimbing Skripsi II

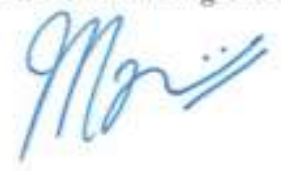

Marisi Debora S.Pd.,M.Hum. NIP.19820415 200604 2003

Ketua Prodi Sastra Inggris

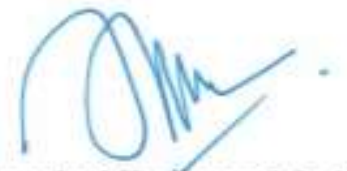

Juli Rachmadani Hasibuan, S.S., M.Hum.

NIP. 198207112008012008 


\title{
COHESIVE DEVICES IN ENGLISH DEPARTMENT STUDENTS' RESEARCH ARTICLES
}

\author{
*TRIANA \\ **AMRIN SARAGIH \\ **MARISI DEBORA
}

\begin{abstract}
This study deals with investigating cohesive devices in English department students' research articles. This study aims at discovering types of cohesive devices and explaining why they are used in English department students' research articles. Qualitative content analysis was utilized as a research design in this study. The data were in the form of clauses obtained from introduction part of 5 articles written by English department students. From the data analysis, it was discovered that there are 4 types of cohesive devices found namely reference, substitutions, ellipsis, and conjunction totaling to 593 occurrences with the dominant type is reference totaling to 419 instances $(70.66 \%)$. The factors affecting the use of cohesive devices are the number of sentences and clauses in the articles. Article with high cohesion tend to have more sentences than the others with middle and low cohesion. The highly cohesive texts employ more cohesive devices because there are more ideas to connect in relation to the number of sentences.
\end{abstract}

Keywords: cohesive devices, research articles, content analysis

*Graduate

** Lecturer 


\section{INTRODUCTION}

\section{The Background of the Study}

Text has its own structure or texture. A text which is too difficult and employs too complex grammatical constructions and lexical items, is likely to cause frustration. Texts must be properly graded and sequenced so that they can meet the abilities and develop the reading comprehension of the students (Broughton, et al., 2003:102). A text has "linguistic features" which can be identified as contributing to its total unity and giving it texture" (Halliday and Hasan, 1976:2). In applying a semantic tie between one sentence and another sentence, it can produce cohesion.

Cohesion is an aspect of discourse legitimately open to analysis. There is another aspect of language that also relates to a text's connectedness and wholeness, though: one which is usually distinguished from cohesion - coherence. Where cohesion looks at the textual, semantic and syntactic connectedness of an utterance, coherence looks at the functional connectedness of the utterance. Thus it involves the study of such factors as the language users' knowledge of the world, the inferences they make and the assumptions they hold. According to Halliday and Hasan, text is not merely sentences in sequence, instead it is "a semantic unit; a unit not of form but of meaning" (Halliday and Hasan, 1976:1).

As a partial requirement to obtain a bachelor degree in English and Literature department Faculty of Languages and Arts, State University of Medan, The bachelor candidate should write an article based on their research in collaboration with the thesis consultant(s) to be published in a certain journal. There are three academic 
covering many fields managed and published by this department namely: Register, Genre, and Linguistica. Writing a scientific paper should follow some rules in academic writing such as template, language, citation style, plagiarism, and word limitation. It also inevitably requires appropriate cohesion and coherence in order to be accepted as academic writing.

The use of cohesive devices is one of many things to be considered in writing as Halliday and Hassan (1976:28-30) argue that the importance of cohesive as well as coherence discourse in order to achieve well-constructed and understandable writing. This makes sense that the language used in the article should be effective in terms of quantity and quality so that it is easily understood by the readers.

There were some previous researches related to this research such as Tsareva (2010), Ahmed (2013), and Kuncahya (2015). Tsareva conducted a research about grammatical cohesion in argumentative essays by Norwegian and Russian learners. The findings present that the examination of grammatical cohesion in the texts of Norwegian and Russian learners shows that argumentative essays do not differ greatly in the number of cohesive items. A difference is, however, observed in the way these items signal different types of cohesion. Another research, Ahmed (2013) deals with A Systemic Functional Investigation of Lexical Cohesion and Schematic Structure in Research Articles on Islam and Science. Kuncahya also conducted a research about Cohesion in Narrative Texts Presented in the Electronic Textbook of Senior High School Grade X Entitled "Developing English Competence". Those researches stated in advance have differences with the research which will be 
conducted by writer. The differences are in the form of object of the study and the limitation of the study.

Considering the phenomenon presented in advance, the problems of the study are formulated as the following:

1. What kinds of cohesive devices are used in English department students' research articles?

2. Why are the cohesive devices used as they are in English department students' research articles?

\section{REVIEW OF LITERATURE}

\section{Cohesion}

Azzouz (2009) asserts that cohesion is the first standard of textuality; it refers to the surface relations between the sentences that create a text i.e. to create connected sentences within a sequence. Jabeen, et al., (2013:139) state that cohesion is all about the relation of meaning in a text. It defines something as a text because a text is unit of meaning, not a form. It is the source of the text that has a range of meanings related to what is being spoken and written to its semantic environment. Halliday and Hasan (1976) use the term cohesion to refer to non-structural text forming relations. They play a special role in creating a text, but they do not constitute structure. Text-forming relations are properties of a text. They serve to link information within a text. This is achieved through relations in meaning.

Halliday and Hasan (1976) classify cohesion into grammatical and lexical cohesion. The grammatical cohesion includes reference, substitution, ellipsis, and conjunction. Meanwhile, lexical cohesion includes repetition and collocation. This is 
because both of them are established by two different elements. They are grammar and words. In the lexico-grammatical level, the distinction can absolutely be drawn.

\section{Grammatical Cohesion}

\section{Reference}

Reference uses other signaling items (words or parts) in making meaning instead of semantic meaning of that reference. It requires referential meaning to interpret what signaling items represent. That is why reference is defined as a particular type of cohesion which has specific meaning of information that is referred to.

Types of reference and reference items can only be identified based on potential reference regardless whether it is endophora or exophora. A reference item is an item that has potential reference and a systemic account on the different types of reference and their place has to be based on generalized concept of reference (not particular form). In addition, there are three types of reference. They consist of personal reference, demonstrative reference, and comparative reference.

\section{Substitution}

Substitution is defined as a replacement of an item with another item. Both items should have the same grammatical class. It is different from reference in which the item that is referred to should have the same semantic property. Substitution is mainly textual. It connects a links between parts of a text anaphorically and encloses them to the text. Exophoric substitution is very rare. The Differences between Reference and Substitution can be seen in the following table (Halliday \& Hasan, 1976: 39). 
The types of substitution might be defined grammatically instead of semantically and should be based on the grammatical function of the substitute item. It can be as a noun, verb or clause. These correspond with the three types of substitution which are nominal, verbal, and clausal substitution.

Nominal substitution is defined as a noun-substituting process which uses "one", "ones", and "same". It means that the item that is substituted with one or ones should be the head of nominal group, since one or ones always function as the head of nominal group.

Verbal substitution operates as head of verb group and its position is always final in the group. The item that supplies the substitution area is "do". While one always substitutes for a noun which expresses typically a person, creature, object, institution, or abstraction of some kind, "do" may substitute either a verb or a verb plus certain other element in the clause which represents an action, event, or relation. It can be expressed by "do", "do so", "can do", "can", "does", "did", and "done”.

Clausal substitution substitutes an entire clause instead of within the clause. The clausal substitution is expressed by the word "so" and "not". Three environments that clausal substitution takes place are report, condition, and modality. It may take either positive or negative form. The positive form is expressed by "so", and the negative form is expressed by "not".

\section{Ellipsis}

Ellipsis is a matter of structural relation. It is established within the sentence. There is no structural relation between the sentences. Thus, there is no need to add additional idea of cohesion to make sentences hang together. Even, by explaining the 
structure within the sentence, it shows the relation between the sentence and it is important aspect of texture. That is why ellipsis is really important for grammatical cohesion and written discourse analysis.

There are three types of ellipsis (Halliday and Hasan, 1976). They are nominal, verbal and clausal ellipsis. Again, the names of the types suggest the items that are omitted. Nominal ellipsis is a type of ellipsis in the nominal group. The nominal ellipsis lifts a word positioning as pre modifier (deictic, numerative, epithet, or classifiers) to Head. Verbal ellipsis refers to ellipsis within the verbal group. The verbal group before presupposes the next verbal group which is not fully expressed in its systemic features. The interpretation is made within the verbal group system. The last one is The clause in English consists of two elements which are modal and propositional elements. Modal element consists of subject and the finite element in the verbal group. The propositional element includes the remainder of the verbal group and any complement or adjunct that may be occurred. The different of complement and adjunct is the complement can become a subject if the clause was turned around in some ways, whereas the adjunct could not. The clausal ellipsis includes the omission in the modal and prepositional elements.

\section{Conjunction}

Conjunctive elements are primarily devices to create cohesion by the virtue of their specific meanings (Halliday and Hasan, 1976). It means that they by themselves express certain meanings and their meanings enable them to presuppose the presence of the other elements. They can relate to the preceding or following text. By 
specifying the way that is the next is semantically connected to what has gone before, conjunction can establish the semantic relation.

In the point of view of cohesion, conjunction is seen from their actual sequence in the text. It is because in connecting the sentences, sentences of a text can only follow one after the other. Hence, the focus is not semantic relation, but it is their function in relating linguistic elements that occur in succession (sequence). Again, conjunction is not only a matter of connecting two sentences, but also relating two events semantically.

There are four types of conjunction. They are additive, adversative, causal, and temporal. They have different signal words and they relate sentences in different ways based on their actual meanings.

\section{Linguistica Journal}

Linguistica: Journal of Linguistics of FBS Unimed (ISSN: 2301-5152) is published by English Language and Literature Department of Unimed. This journal is a quarterly publication presenting articles on Linguistics. The contents include analyses, studies, applications of theories, research reports and reviews. This journal published its first edition in 2012. This journal can be accessed on http://jurnal.unimed.ac.id/2012/index.php/jalu/index. It also provides immediate open access to its content on the principle that making research freely available to the public supports a greater global exchange of knowledge. It is now indexed in Google Scholar. In order to submit manuscript to this journal, the writer should pay attention on the submission checklist and must be done online. 


\section{RESEARCH METHOD}

The Design

This study was conducted in a qualitative content analysis. Qualitative research is an approach to explore observable social phenomenon. Scott and Morrison (2006:182) hold that qualitative research is a research approaches that are underpinned by a set of assumptions about the way he social world operates. Moreover, Cohen, Manion \& Morrison (2007) argue that qualitative content analysis is the process of summarizing and reporting written data - the main contents of data and their messages. This research has a purpose to describe the types of cohesive devices and why they are used in English department students' research article. Since the data are in the form of document, qualitative content analysis is very appropriate to be utilized as a research design in this study.

The Data and Source of the Data

The data of this research were in the form of clauses since the analysis was conducted by using cohesive devices based on theory proposed by Halliday and Hasan (1976) and in systemic functional linguistic the focus is clause not sentence. Purposive sampling technique was used in this research. It means that the samples were selected based on the needs and the purposes of the study (Cohen, Manion \& Morrison, 2007). The source of data were taken from the background part in the introduction section of 5 articles downloaded from Linguistica: Journal of Linguistics of FBS Unimed (ISSN: 2301-5152) published by English Language and Literature Department of Unimed Vol 6 No.4, Oct-Dec 2017 edition. This journal is a quarterly publication presenting articles on Linguistics. The contents include analyses, studies, 
applications of theories, research reports and reviews. The reason in choosing this journal is because the journal is regularly published and has been indexed in Google Scholar.

\section{The Instrument}

The main instrument in this research was the researcher herself. She acted as the planner, data collector, analyst, and finally the reporter of the research findings. Moreover, the researcher used related documents, computer, and data sheets. Related documents and computer were utilized to ease the organization of the data. Meanwhile, the use of data sheets had an aim to enable the classification of the data and to note the number of occurrences and percentages of the classification. The categories were adapted from Halliday and Hasan (1976: 340) and the coding scheme was modified based on the researcher's need.

The Procedures

Qualitative analysis technique was utilized to analyze the data. This was conducted through some procedures, namely data collection and data analysis.

\section{Data Collection}

The data collection in this research took the following steps below:

a. Collecting the data by downloading the articles from Linguistica: Journal of Linguistics of FBS Unimed (ISSN: 2301-5152) published by English Language and Literature Department of Unimed Vol 6 No.4, Oct-Dec 2017 edition through e-journal.unimed.ac.id.

b. Separating the text in the background of the study of each article into unit of clauses as the data to be analyzed. 
c. Putting the clauses into the table.

d. Coding the data.

\section{Data Analysis}

The data used in this study were analyzed by using cohesive devices. Since the data were carried out from document, a suitable method of analysis data was qualitative content analysis. The procedures of the data analysis were adapted from Miles, Huberman and Saldana (2014:31-33) presented as the followings:

a. Data making: It consists of unitizing, sampling, and documenting

b. Data reduction: statistically and simply omission of irrelevant data

c. The analysis: concerning with the more conventional process of identification and representation of patterns that are statistically significant namely writing down the frequency of occurrence of each type of cohesive devices.

d. Inferences making: The direct evidence about the inferred phenomena is characterized by the results of analysis and validation efforts. 


\section{DATA ANALYSIS, FINDINGS, AND DISCUSSION}

Data Analysis

Table 1.

Cohesive Devices Percentage

\begin{tabular}{|c|c|c|c|c|c|c|c|c|c|c|c|c|c|c|}
\hline \multirow{3}{*}{ Texts } & \multicolumn{13}{|c|}{ Cohesive Device Categories } & \multirow{3}{*}{ Total } \\
\hline & \multicolumn{3}{|c|}{ Reference } & \multicolumn{3}{|c|}{ Substitutions } & \multicolumn{3}{|c|}{ Ellipsis } & \multicolumn{4}{|c|}{ Conjunction } & \\
\hline & RI & RII & RIII & SI & SII & SIII & EI & EII & EIII & CI & CII & CIII & CIV & \\
\hline 1 & 31 & 85 & 3 & 1 & 0 & 0 & 0 & 0 & 0 & 28 & 2 & 8 & 3 & 161 \\
\hline 2 & 12 & 43 & 10 & 0 & 0 & 0 & 0 & 0 & 0 & 20 & 2 & 2 & 3 & 95 \\
\hline 3 & 35 & 48 & 14 & 1 & 0 & 0 & 1 & 0 & 0 & 19 & 12 & 13 & 7 & 150 \\
\hline 4 & 20 & 33 & 5 & 0 & 0 & 0 & 0 & 3 & 2 & 19 & 0 & 8 & 2 & 89 \\
\hline 5 & 29 & 42 & 9 & 0 & 0 & 0 & 0 & 0 & 0 & 11 & 1 & 5 & 1 & 98 \\
\hline \multirow{3}{*}{$\begin{array}{l}\text { Tot } \\
\% \\
\text { Tot } \\
\end{array}$} & 127 & 251 & 41 & 2 & 0 & 0 & 1 & 3 & 2 & 97 & 17 & 36 & 16 & 593 \\
\hline & 21.42 & 42.33 & 6.91 & 0.34 & 0 & 0 & 0.17 & 0.51 & 0.34 & 16.36 & 2.87 & 6.07 & 2.70 & 100.00 \\
\hline & \multicolumn{3}{|c|}{419} & \multicolumn{3}{|c|}{2} & \multicolumn{3}{|c|}{6.00} & \multicolumn{4}{|c|}{166} & 593 \\
\hline$\%$ & \multicolumn{3}{|c|}{70.66} & \multicolumn{3}{|c|}{0.34} & \multicolumn{3}{|c|}{1.01} & \multicolumn{4}{|c|}{27.99} & 100.00 \\
\hline
\end{tabular}

\section{Codes:}

RI : Personal Reference

RII : Demonstrative Reference

RIII : Comparative Reference

CI : Additive Conjunction

CII : Adversative Conjunction

CIII : Causal Conjunction

CIV : Temporal Conjunction
SI

SII

SIII

EI

EII

EIII
: Nominal Substitution

: Verbal Substitution

: Clausal Substitution

: Nominal Ellipsis

: Verbal Ellipsis

: Clausal Ellipsis

From table 1, it presents that the highest usage of cohesive devices is in article 1 totaling to 161 occurrences and the lowest one is in article 4 . The highest occurrence of cohesive devices is reference specifically demonstrative reference (RII) totaling to $251(42.33 \%)$. Verbal and clausal substitutions are not found in the data. 


\section{Findings}

After the data have been analysed, the findings are presented in the following points:

1. There are 4 types of cohesive devices found in the data namely reference, substitutions, ellipsis, and conjunction. Those have 593 occurrences in total with the dominant type is reference totaling to 419 instances $(70.66 \%)$ followed by conjunction $166(27.99 \%)$, ellipsis $6(1.01 \%)$, and substitutions 2 $(0.34 \%)$

2. The factors affecting the use of cohesive devices are the number of sentences and clauses in an article. The number of clauses and sentences will affect the use of cohesive ties. Article with high cohesion tend to have more sentences than the others with middle and low cohesion. The highly cohesive texts employ more cohesive devices because there are more ideas to connect in relation to the number of sentences.

\section{Discussion}

A text has "linguistic features" which can be identified as contributing to its total unity and giving it texture" (Halliday and Hasan, 1976:2). They also claim that the use of cohesive devices is one of many things to be considered in writing in order to achieve well-constructed and understandable writing. Writing an article is not easy (Hanafiah and Yusuf, 2016) since it needs more technical language related to a certain field. The goal of writing an article is to make the reader understand about what ideas or messages conveyed through our writing. reference and conjunction are 
used extensively to establish cohesive relations that hold between sentences (Tsareva, 2010).

The findings of this study assert that reference and conjunction are dominantly used in English department students' research article. The findings are also in line with Abdurahman, Wijaya, and Salam (2013), and Bahaziq (2016). They found that reference and conjunction are the types used dominantly in bachelor student thesis even though substitutions and ellipsis are also used with fewer percentages. The findings of this study also supports their findings since both of these researches are focused on the products of the students' writing (essay, thesis, and article). This research also found the low use of substitutions and ellipsis types in the data. Thompson (2004: 184) has his argument related to this by stating that ellipsis is typically more fully exploited in speech than in writing.

\section{CONCLUSIONS AND SUGGESTIONS}

\section{Conclusion}

Based on the findings and discussion, there are 4 types of cohesive devices found in the data namely reference, substitutions, ellipsis, and conjunction. Those have 593 occurrences in total with the dominant type is reference totaling to 419 instances $(70.66 \%)$ followed by conjunction $166(27.99 \%)$, ellipsis $6(1.01 \%)$, and substitutions $2(0.34 \%)$. Then, The factors affecting the use of cohesive devices are the number of sentences and clauses in the articles. The number of clauses and sentences will affect the use of cohesive ties. Article with high cohesion tend to have more sentences than the others with middle and low cohesion. The highly cohesive 
texts employ more cohesive devices because there are more ideas to connect in relation to the number of sentences.

\section{Suggestions}

In accordance to the conclusion, the suggestions are proposed as the followings:

1. The researcher suggests the students of English department should learn and make use knowledge about cohesive devices in order to make an improvement of their writing.

2. This research is expected to be contributive enough for thesis consultant as the source of information in supervising and reviewing the students' article in order to make sure that the article submitted by students are well-organized and well-produced.

3. The researcher suggests further researcher should explore more on article written by students such as metafunction realization and error analysis.

\section{REFERENCES}

Ahmed, A.A.A. 2013. A Systemic Functional Investigation of Lexical Cohesion and Schematic Structure in Research Articles on Islam and Science. Dissertation. Kuala Lumpur: University of Malaya.

Abdurrahman, N.H., Wijaya, B., and Salam, U. 2013. Grammatical Cohesion Analysis of Students' Thesis Writing. Jurnal Pendidikan dan Pembelajaran, 2 (11).

Azzouz, B. 2009. A Discourse Analysis of Grammatical Cohesion in Student's Writing. Dissertation. Algeria: Mentouri University-Constantine. 
Bahaziq, A. 2016. Cohesive Devices in Written Discourse: A Discourse Analysis of a Student's Essay Writing. English Language Teaching, 9 (7), 112-119.

Broughton, G., et al. 2003. Teaching English as a Foreign Language. New York: Routledge.

Cohen, L., Manion, L., and Morrison, K. 2007. Research Methods in Education (6 ${ }^{\text {th }}$ ed.). New York: Routledge.

Halliday, M. A. K., and Hasan, R. 1976. Cohesion in English. London: Longman.

Hanafiah, R., \& Yusuf, M. 2016. Lexical density and grammatical intricacy in linguistic thesis abstract: A qualitative content analysis. Proceedings Of English Education International Conference, 1(2), 43-46. Retrieved from http://capeu.unsyiah.ac.id/proceedings/index.php/eeic/article/view/14

Jabeen, I., et al. 2013. Cohesion and Semantic Understanding. Academic Research International, 4 (6) 139-148.

Kuncahya, A. O. 2015. Cohesion in Narrative Texts Presented in the Electronic Textbook of Senior High School Grade X Entitled "Developing English Competence. Bachelor Thesis. Yogyakarta: Universitas Negeri Yogyakarta.

Miles, M.B, Huberman, A.M, dan Saldana, J. 2014. Qualitative Data Analysis, A. Methods Sourcebook, $3^{\text {rd }}$ edition. New York: Sage Publications.

Scott, D., and Morrison, M. 2006. Key Ideas in Educational Research. London: Continuum.

Tsareva, A. 2010. Grammatical Cohesion in Argumentative Essays by Norwegian and Russian Learners. Master Thesis. Oslo: The University of Oslo.

Thompson, G. 2004. Introducing Functional Grammar $\left(2^{\text {nd }} e d\right)$. London: Hodder Education. 